\title{
Differential mechanisms of glucose and palmitate in augmentation of insulin secretion in mouse pancreatic islets
}

\author{
P. Thams, K. Capito \\ Department of Medical Biochemistry and Genetics, The Panum Institute, University of Copenhagen, Copenhagen, Denmark
}

\section{Abstract}

Aims/hypothesis. To assess the possible importance of saturated fatty acids in glucose amplification of $\mathrm{K}^{+}$ATP channel-independent insulin secretion.

Methods. Insulin release from perifused pancreatic islets of NMRI mice was determined by radioimmunoassay.

Results. In the presence of $\mathrm{K}^{+}(20 \mathrm{mmol} / \mathrm{l})$ and diazoxide $(250 \mu \mathrm{mol} / \mathrm{l})$, which stimulates $\mathrm{Ca}^{2+}$ influx and opens $\mathrm{K}^{+}$ATP channels, palmitate $(165 \mu \mathrm{mol} / \mathrm{l}$ total; $1.2 \mu \mathrm{mol} / \mathrm{l}$ free) increased insulin secretion at 3.3, 10 and $16.7 \mathrm{mmol} / \mathrm{l}$ glucose while glucose (10; $16.7 \mathrm{mmol} / \mathrm{l})$ did not increase insulin secretion. In the presence of $\mathrm{K}^{+}(60 \mathrm{mmol} / \mathrm{l})$ and diazoxide $(250 \mu \mathrm{mol} / \mathrm{l})$, glucose $(10 ; 16.7 \mathrm{mmol} / \mathrm{l})$ stimulation of $\mathrm{K}^{+}{ }_{\text {ATP }}$ channel-independent insulin secretion increased, whereas the effectiveness of palmitate $(165 \mu \mathrm{mol} / 1$ total; $1.2 \mu \mathrm{mol} / 1$ free $)$ on insulin secretion at both $3.3,10$ or $16.7 \mathrm{mmol} / \mathrm{l}$ glucose was reduced. Palmitate thereby mimicked the stimulatory pattern of the protein kinase $\mathrm{C}$ activator, 12-O-tetradecanoylphorbol 13 -acetate $(0.16 \mu \mathrm{mol} / \mathrm{l})$, which also failed to increase insulin secretion at maximum depolarising concentrations of $\mathrm{K}^{+}(60 \mathrm{mmol} / \mathrm{l})$. Furthermore, the protein kinase $C$ inhibitor calphostin $C(1 \mu \mathrm{mol} / \mathrm{l})$, led to a complete suppression of the effects of both palmitate $(165 \mu \mathrm{mol} / \mathrm{l}$ total; $1.2 \mu \mathrm{mol} / \mathrm{l}$ free $)$ and myristate $(165 \mu \mathrm{mol} / \mathrm{l}$ total; $2.4 \mu \mathrm{mol} / \mathrm{l}$ free $)$ stimulation of glucose $(16.7 \mathrm{mmol} / \mathrm{l})$-induced insulin secretion. Calphostin C $(1 \mu \mathrm{mol} / \mathrm{l})$, however, failed to affect insulin secretion induced by glucose $(16.7 \mathrm{mmol} / \mathrm{l})$. Conclusion/interpretation. These data suggest that glucose could increase insulin secretion independently of saturated fatty acids like palmitate and myristate, which amplify glucose-induced insulin secretion by activation of protein kinase C. [Diabetologia (2001) 44: 738-746]

Keywords Mouse islets, palmitate, glucose, insulin secretion, protein kinase $\mathrm{C}$
It is generally agreed that to stimulate insulin secretion, glucose must first enter the beta cell and then be metabolized to a point beyond pyruvate. This in

Received: 30 October 2001 and in revised form: 31 January 2001

Corresponding author: P. Thams, Dept. of Medical Biochemistry and Genetics, Biochemistry Laboratory A, The Panum Institute, University of Copenhagen, 3C Blegdamsvej, DK-2200, Copenhagen N, Denmark

Abbreviations: HSA, Human serum albumin; TES, 2-((2-hydroxy-1,1-di(hydroxymethyl)-ethyl)-amino)ethanesulfonic acid; TPA, 12-O-tetradecanoylphorbol 13-acetate turn is thought to cause an increase in the ATP:ADP ratio, closure of the cell surface $\mathrm{K}^{+}{ }_{\text {ATP }}$ channels, cell depolarisation and opening of the voltage-sensitive $\mathrm{Ca}^{2+}$ channels, leading to a rise in intracellular $\mathrm{Ca}^{2+}$ and an activation of exocytosis [1]. Other mechanisms contributing to the glucose regulation of insulin secretion relate both to the $\mathrm{K}^{+}{ }_{\text {ATP }}$ channel-independent pathway, which augments the response to a rise in intracellular $\mathrm{Ca}^{2+}$ concentrations [1-3] and, to a lesser extent, to the $\mathrm{K}^{+}{ }_{\text {ATP }}$ channel-independent, $\mathrm{Ca}^{2+}$-independent pathway of glucose signalling, operating in $\mathrm{Ca}^{2+}$-deprived islets. There it is activated by the combined effects of protein kinase $\mathrm{A}$ and protein kinase $C[1,4]$. 
According to the "long-chain acylCoA hypothesis" [5-7], endogenous cytosolic long-chain acylCoAs act as signal transduction intermediates in glucose-induced insulin secretion. Thus glucose administration could result in an increase in long-chain acylCoA by increasing malonylCoA concentrations that inhibit the mitochondrial enzyme carnitine palmitoyltransferase I and therefore fatty acid oxidation [5-7]. The hypothesis has, however, not been fully validated. Thus a reduction of malonylCoA concentrations in INS-1 insulinoma cells or the inhibition of long-chain acylCoA synthetase in rat islets was not found to affect glucose-induced insulin secretion [8]. Furthermore, exogenously added fatty acids, which increase intracellular long-chain acylCoA concentrations, have not been found to mimic but only to increase the capacity of glucose to stimulate $\mathrm{K}^{+}$ATP channel-independent insulin secretion $[9,10]$. Other data from recent studies have shown that both palmitate and myristate might indeed mimic glucose in their stimulation of $\mathrm{K}_{\text {ATP }}^{+}$channel-independent, $\mathrm{Ca}^{2+}$-dependent insulin secretion as observed in the presence of depolarising concentrations of $\mathrm{K}^{+}$and the $\mathrm{K}^{+}{ }_{\text {ATP }}$ channel opener diazoxide [11]. Furthermore, fatty acids have also been observed to mimic the capacity of glucose to increase $\mathrm{K}^{+}{ }_{\text {ATP }}$ channel-independent, $\mathrm{Ca}^{2+}$-independent insulin secretion in the absence of $\mathrm{Ca}^{2+}$ and in the presence of both the protein kinase $\mathrm{C}$ activator 12-O-tetradecanoylphorbol 13-acetate (TPA) and the adenylate cyclase activator forskolin [12]. In contrast to former studies $[9,10]$ in mouse islets, these studies were performed in rat islets after pre-incubation in $\mathrm{Ca}^{2+}$-deprived medium, which increased the stimulatory capacity of the fatty acids $[11,12]$. Finally, a significant role for fatty acids in insulin secretion is indicated by the restoration by fatty acids of insulin secretion to both glucose and non-glucose stimuli in islets from fasted rats [13,14].

The mechanisms by which fatty acids modulate beta-cell function have not been fully characterized. Observations that palmitate is oxidized in islet cells indicate that their mode of action is similar to that of glucose [15]. However, palmitate does not stimulate $\mathrm{Ca}^{2+}$ influx and insulin secretion at non-stimulatory glucose concentrations [9], and fatty acids actually appear to open $\mathrm{K}^{+}{ }_{\text {ATP }}$ channels [16]. Another view is that the esterification, rather than the oxidation of fatty acids, is important for the stimulation of insulin release [17]. Furthermore, some data suggest that palmitate, as opposed to glucose, exhibits a glucosedependent translocation of protein kinase $\mathrm{C}$ in rat islets [17]. However, palmitate failed to stimulate protein kinase $\mathrm{C}$ translocation in HIT insulinoma cells [6] and increases by palmitate of glucose-induced insulin secretion from mouse islets seem not to be affected by the non-specific protein kinase $\mathrm{C}$ inhibitor staurosporine [9] but appear to be inhibited by the specific protein kinase C inhibitor Ro 31-8220 and not by Gö 6976 an inhibitor of conventional protein kinase $\mathrm{C} \alpha$ and $\beta_{\mathrm{I}}$ isoforms [18]. In addition, it has been suggested that long-chain acylCoA activates exocytosis in HIT insulinoma cells and rat beta cells in a process not affected by the protein kinase $\mathrm{C}$ inhibitor calphostin C [19].

Both conventional $\left(\mathrm{Ca}^{2+}\right.$, diacylglycerol- and PSdependent $)$, novel $\left(\mathrm{Ca}^{2+}\right.$-independent, but diacylglycerol- and PS-dependent) and atypical $\left(\mathrm{Ca}^{2+}\right.$ - and diacylglycerol-independent, but PS-dependent) protein kinase $\mathrm{C}$ isoforms have been identified in beta cells [20]. According to recent data long-chain acylCoAs could even directly activate the atypical protein kinase $\mathrm{C} \xi$ in HIT insulinoma cells [21]. Protein kinase $\mathrm{C} \zeta$, a calphostin C-sensitive [22] but staurosporineinsensitive isoform [23], has previously been observed in glucose-stimulated insulin gene expression in MIN 6 cells [24] and seems to be both fatty acid and glucose-sensitive [21].

In this study we therefore aimed at an analysis of both the similarities and/or dissimilarities in fatty acids and glucose in the stimulation of $\mathrm{K}^{+}{ }_{\text {ATP }}$ channelindependent insulin secretion in intact mouse islets. In addition, the role of protein kinase $\mathrm{C}$ was assessed using the protein kinase $\mathrm{C}$ inhibitor calphostin $\mathrm{C}$.

\section{Materials and methods}

Materials. Crude bacterial collagenase was obtained from Boehringer, Mannheim, Germany. Human serum albumin (HSA) was from Behringswerke AG, Marburg, Germany. The $\left[{ }^{125} \mathrm{I}\right]$ Insulin and guinea-pig anti-insulin serum were from Novo Nordisk A/S, Bagsværd, Denmark and $\left[\gamma_{-}{ }^{32} \mathrm{P}\right]$ ATP was from Amersham International, Amersham, Buckinghamshire, UK. Phosphatidylserine (PS), lysine-rich histone (type III-S), forskolin, TPA, diazoxide, dimethyl sulfoxide (DMSO), palmitic acid, myristic acid and palmitoylCoA were from Sigma Chemical Co (St. Louis, Mo., USA). Calphostin C was from Calbiochem (San Diego, Calif., USA). Verapamil was from RBI (Natick, Mass., USA). All other chemicals were of analytical grade.

Preparation and culture of islets. Islets were prepared by collagenase digestion of the pancreas of male albino mice (NMRI mice; Charles River, Sulzfeldt, Bayern, Germany). Mice had approximately 18-22 g body weight. Islets were kept in tissue culture for 22-24 h in TCM 199 medium as previously described [25]. Principles of laboratory animal care (NIH publication No. 85-23) were followed.

Insulin release. Insulin release from islets was determined by perifusion in a non-circulating system with beads of $0.25 \mathrm{ml}$ Bio-Gel P2 (Bio-Rad Laboratories, Rockville Center, N.Y. USA) as a supporting medium [25]. Altogether 25 islets per chamber were perifused at $37^{\circ} \mathrm{C}$ at a flow rate of $0.26 \mathrm{ml} / \mathrm{min}$. The perifusion medium was Krebs-Ringer medium supplemented with $20 \mathrm{mmol} / \mathrm{l} \mathrm{HEPES}, 5 \mathrm{mmol} / \mathrm{l} \mathrm{NaHCO}, 2 \mathrm{mg}$ of human serum albumin/ml and $3.3 \mathrm{mmol} / \mathrm{l}$ glucose $(\mathrm{KRH})$.

Static incubation of islets. Groups of 80 islets were pre-incubated at $37^{\circ} \mathrm{C}$ for $45 \mathrm{~min}$ in $600 \mu \mathrm{l}$ of $\mathrm{KRH}$ medium. After pre- 


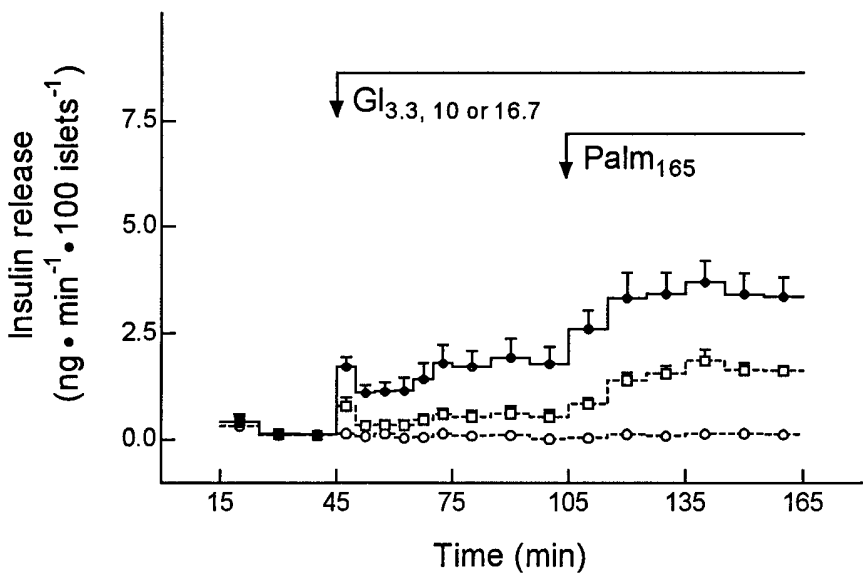

Fig.1. Effects of palmitate on glucose-induced insulin secretion. Islets were perifused at $3.3(\bigcirc), 10(\square)$ or $16.7 \mathrm{mmol} / \mathrm{l}$ glucose (O) $\left(\mathrm{Gl}_{3.3}, 10\right.$ or 16.7$)$ and with $165 \mu \mathrm{mol} / \mathrm{l}$ palmitate $\left(\right.$ Palm $\left._{165}\right)$ as indicated. Results are means \pm SEM $(n=7-8)$

incubation, the medium was replaced by $600 \mu$ of the same medium containing test agents and incubation proceeded for $15 \mathrm{~min}$. At the end of incubation, islets were washed in $600 \mu \mathrm{l}$ of TES (2-((2-hydroxy-1,1-di(hydroxymethyl)-ethyl)-amino) ethanesulfonic acid) buffer, $\mathrm{pH} 6.90$, containing $5 \mathrm{mmol} / \mathrm{l}$ $\mathrm{MgCl}_{2}, 1 \mathrm{mmol} / 1 \mathrm{EGTA}, 0.1 \mathrm{mmol} / \mathrm{l}$ dithiothreitol, $10 \mathrm{mmol} / \mathrm{l}$ benzamidine, $50 \mu \mathrm{mol} / \mathrm{l}$ ATP and $2 \mathrm{mg}$ human serum albumin/ $\mathrm{ml}$ [26], and then sonicated in $300 \mu \mathrm{l}$ of the same medium.

Phosphorylation assay. Protein kinase $\mathrm{C}$ activity was measured as described previously [26]. Samples of islet cytosol or solubilized membrane were incubated for $2 \mathrm{~min}$ at $30^{\circ} \mathrm{C}$ in a reaction medium (final volume $200 \mu \mathrm{l}$ ) containing $25 \mathrm{mmol} / \mathrm{l}$ TES buffer, pH 6.90, $5 \mathrm{mmol} / 1 \mathrm{MgCl}_{2}, 1 \mathrm{mmol} / \mathrm{l} \mathrm{EGTA}, 0.1 \mathrm{mmol} / \mathrm{l} \mathrm{di}-$ thiothreitol, $0.2 \mathrm{mg}$ human serum albumin $/ \mathrm{ml}, 0.2 \mathrm{mg}$ lysinerich histone $/ \mathrm{ml}, 20 \mu \mathrm{mol} / 1\left[\gamma_{-}{ }^{32} \mathrm{P}\right]$ ATP $(200-400 \mathrm{cpm} / \mathrm{pmol})$, and further additions as indicated.

Miscellaneous. TPA, forskolin, diazoxide, verapamil and calphostin $\mathrm{C}$ were added to a small volume of DMSO, final concentration $0.01-0.1 \%$.

Palmitic acid and myristic acid were added after dissolution in $0.1 \mathrm{~mol} / 1 \mathrm{NaOH}$. The total concentration of palmitate or myristate was $165 \mu \mathrm{mol} / \mathrm{l}$, corresponding to a free concentration of approximately $1.2 \mu \mathrm{mol} / \mathrm{l}$ palmitate or $2.4 \mu \mathrm{mol} / 1 \mathrm{myris}-$ tate in KRH medium with $2 \mathrm{mg}$ human serum albumin/ml [27, 28].

Results are given as means \pm SEM for $n$ experiments. Statistical evaluation of the data was made by ANOVA, followed by the Newman-Keuls test for multiple comparisons. We concluded a $p$ value of more than 0.05 not to be significant. For statistical comparisons of the insulin data, the total release during the $60 \mathrm{~min}$ of stimulation was calculated.

\section{Results}

Effects of palmitate on glucose-induced insulin secretion. Palmitate $(165 \mu \mathrm{mol} / 1$ total, $1.2 \mu \mathrm{mol} / 1$ free $)$ increased insulin secretion at $10 \mathrm{mmol} / \mathrm{l}$ and $16.7 \mathrm{mmol} / \mathrm{l}$ glucose, but failed to initiate secretion at $3.3 \mathrm{mmol} / \mathrm{l}$ glucose (Fig. 1 ).

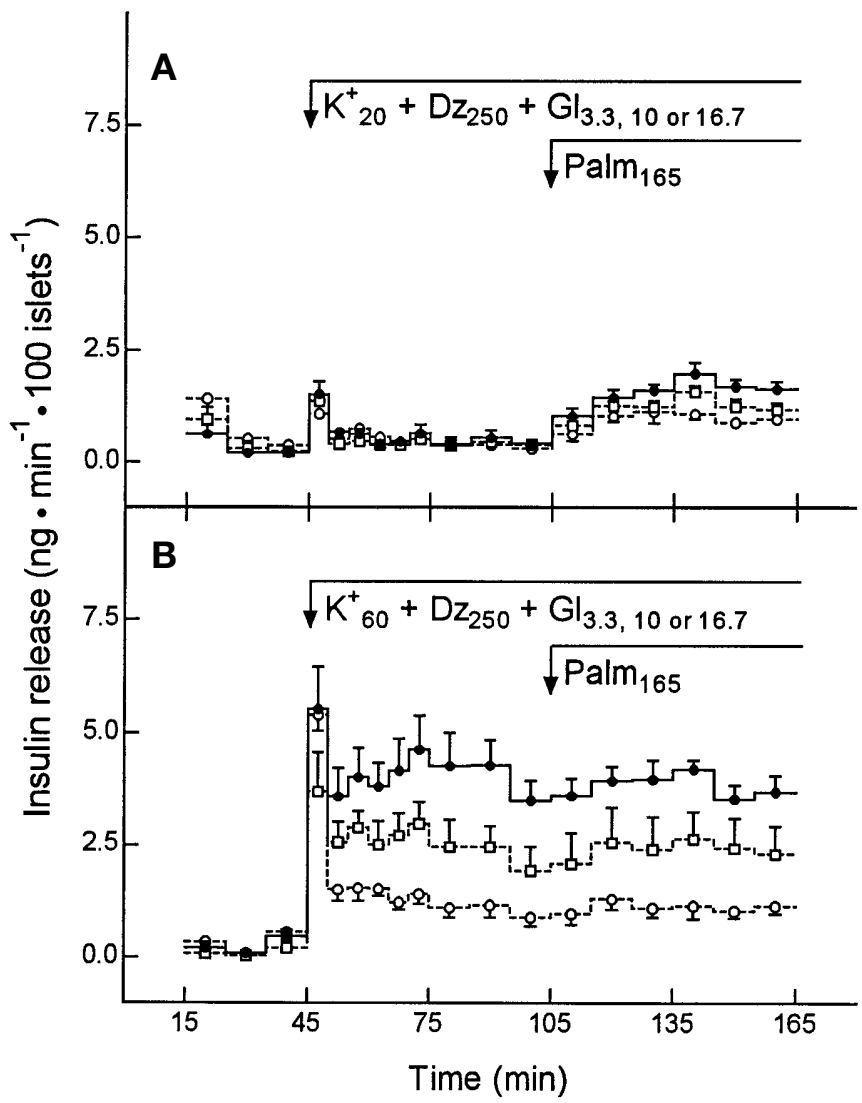

Fig. 2 A, B. Effects of palmitate on $\mathrm{K}^{+}$ATP channel-independent, $\mathrm{Ca}^{2+}$-dependent insulin secretion. Islets were perifused at (A) $20 \mathrm{mmol} / \mathrm{l} \mathrm{K}{ }^{+}+250 \mu \mathrm{mol} / \mathrm{l}$ diazoxide $\left(\mathrm{K}^{+}{ }_{20}+\mathrm{Dz}_{250}\right)$ or (B) $60 \mathrm{mmol} / \mathrm{l} \mathrm{K}^{+}+250 \mu \mathrm{mol} / \mathrm{l}$ diazoxide $\left(\mathrm{K}_{60}^{+}+\mathrm{Dz}_{250}\right)$ with $3.3(\bigcirc), 10(\square)$ or $16.7 \mathrm{mmol} / \mathrm{l}$ glucose $(\bigcirc)\left(\mathrm{Gl}_{3.3,10 \text { or } 16.7)}\right)$ and $165 \mu \mathrm{mol} / \mathrm{l}$ palmitate $\left(\mathrm{Palm}_{165}\right)$ as indicated. Results are means $\pm \operatorname{SEM}(n=3-4)$

Effects of palmitate on $\mathrm{K}^{+}{ }_{\text {ATP }}$ channel-independent, $\mathrm{Ca}^{2+}$-dependent insulin secretion. In the presence of depolarising $\mathrm{K}^{+}$concentrations and the $\mathrm{K}^{+}{ }_{\text {ATP }}$ channel opener diazoxide, glucose stimulation of insulin secretion is confined to an amplification of $\mathrm{Ca}^{2+}$-induced insulin secretion.

At $\mathrm{K}^{+}(20 \mathrm{mmol} / \mathrm{l})$ with diazoxide $(250 \mu \mathrm{mol} / \mathrm{l})$, stimulation of insulin secretion by 10 and $16.7 \mathrm{mmol} /$ 1 glucose was absent (Fig. $2 \mathrm{~A}$ ). At $20 \mathrm{mmol} / \mathrm{l} \mathrm{K} \mathrm{K}^{+}$, palmitate $(165 \mu \mathrm{mol} / \mathrm{l}$ total, $1.2 \mu \mathrm{mol} / \mathrm{l}$ free $)$, however, increased insulin secretion at all three glucose concentrations in a way which was facilitated by 10 or $16.7 \mathrm{mmol} / \mathrm{l}$ glucose (Fig. 2A). Thus palmitate stimulated insulin secretion $90 \%(p<0.05)$ in the presence of $3.3 \mathrm{mmol} / \mathrm{l}$ glucose and this stimulation further increased to $142 \%(p<0.001)$ and $212 \%(p<0.001)$ at glucose concentrations of 10 and $16.7 \mathrm{mmol} / \mathrm{l}$.

In the presence of $\mathrm{K}^{+}(60 \mathrm{mmol} / \mathrm{l})$ and diazoxide $(250 \mu \mathrm{mol} / \mathrm{l})$, which cause maximum membrane depolarisation and $\mathrm{Ca}^{2+}$ influx, glucose $(10,16.7 \mathrm{mmol} / \mathrm{l})$ stimulation of $\mathrm{K}^{+}{ }_{\text {ATP }}$ channel-independent insulin secretion increased (Fig. 2B) by $64 \%(p<0.05)$ and $164 \%(p<0.05)$ at 10 and $16.7 \mathrm{mmol} / 1$ glucose, respec- 


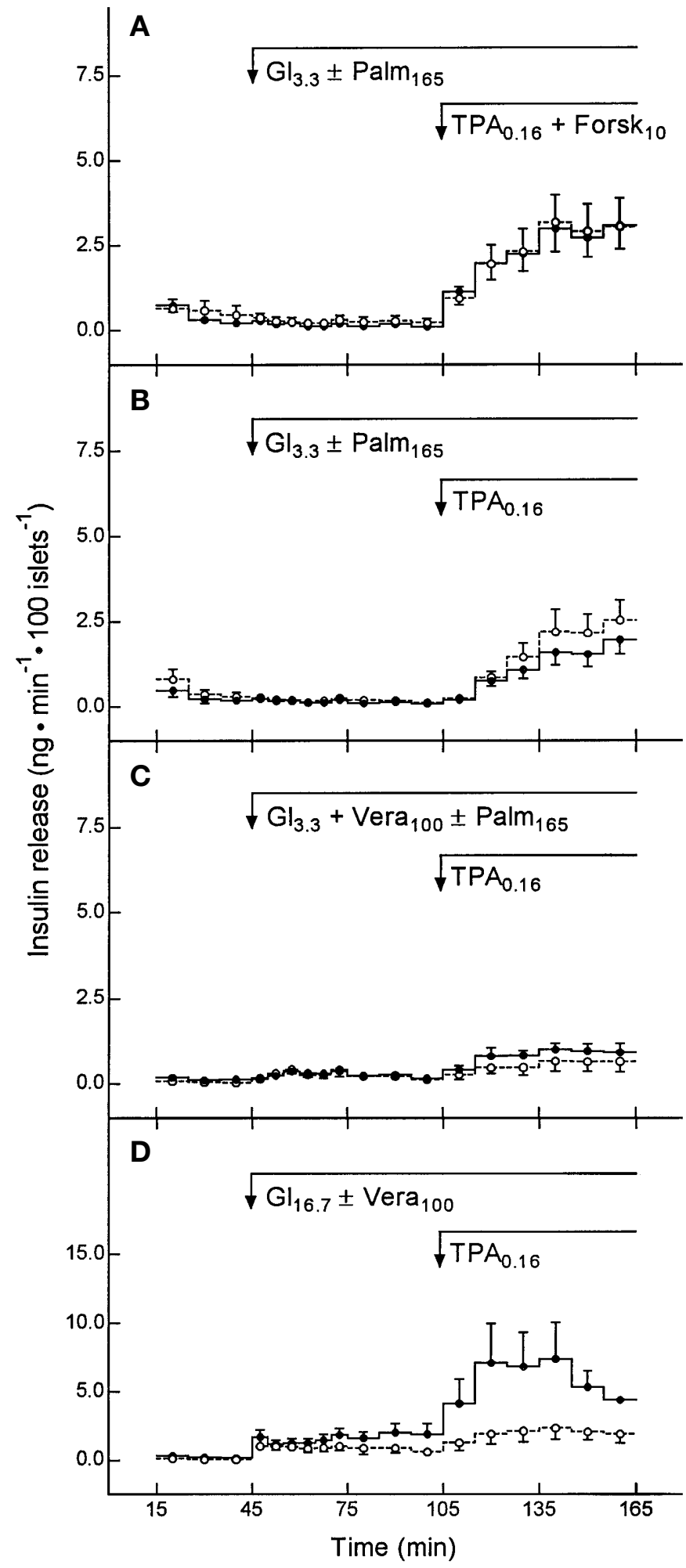

Fig.3 A-D. Effects of palmitate on $\mathrm{K}^{+}{ }_{\text {ATP }}$ channel-independent, $\mathrm{Ca}^{2+}$-independent insulin secretion. $(\mathbf{A}, \mathbf{B}, \mathbf{C}) 3.3 \mathrm{mmol} / \mathrm{l}$ glucose $\left(\mathrm{Gl}_{3.3}\right)$ in the absence $(\mathbf{O})$ or presence $(\bigcirc)$ of $165 \mu \mathrm{mol} / \mathrm{l}$ palmitate $\left(\mathrm{Palm}_{165}\right)$ and with $0.16 \mu \mathrm{mol} / \mathrm{l}$ TPA $\left(\mathrm{TPA}_{0.16}\right)$ and $10 \mu \mathrm{mol} / 1$ forskolin $\left(\right.$ Forsk $_{10}$ ) as indicated. (C) With $100 \mu \mathrm{mol} / \mathrm{l}$ verapamil $\left(\right.$ Vera $\left._{100}\right)$. (D) $16.7 \mathrm{mmol} / \mathrm{l}$ glucose $\left(\mathrm{Gl}_{16.7}\right)$ in the absence $(\bigcirc)$ or presence $(\mathrm{O})$ of $100 \mu \mathrm{mol} / \mathrm{l}$ verapamil and with $0.16 \mu \mathrm{mol} / \mathrm{l}$ TPA as indicated. Results are means $\pm \operatorname{SEM}(n=3-6)$

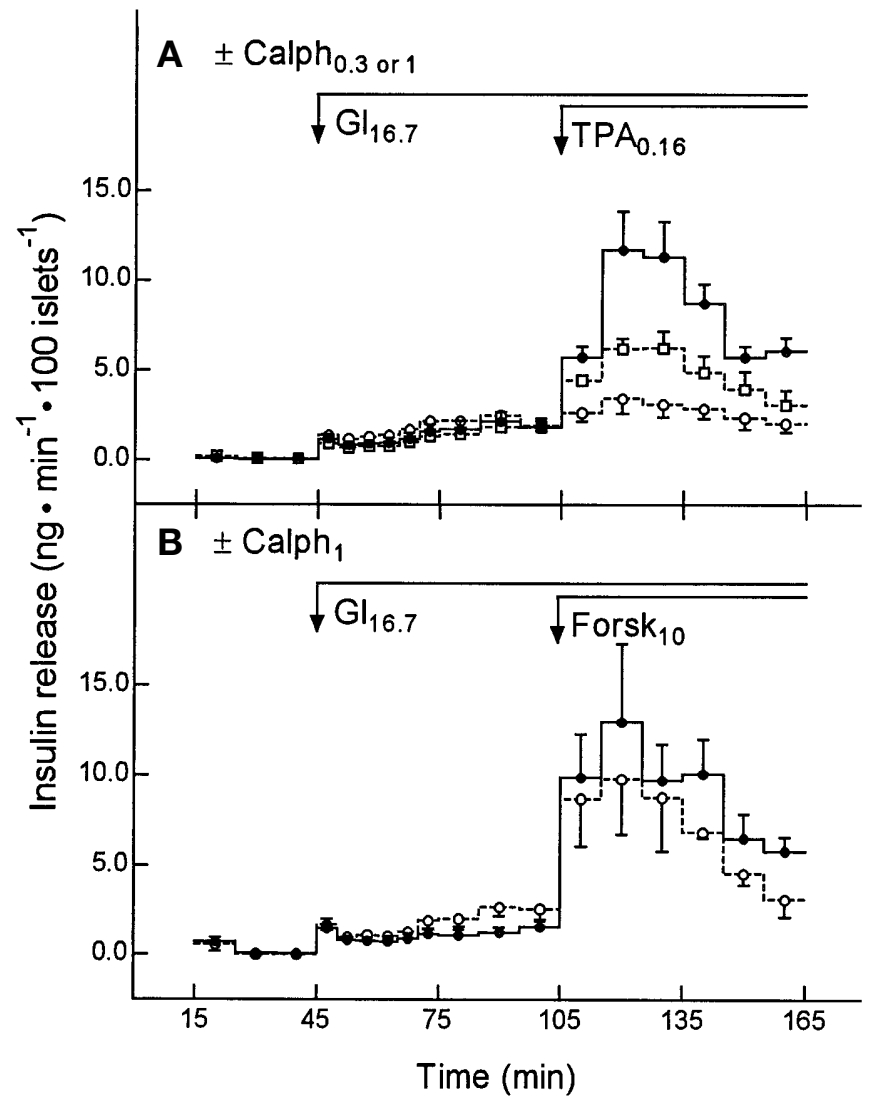

Fig. 4. Effects of calphostin C on glucose-, TPA- and forskolininduced insulin secretion. Islets were perifused without $(\boldsymbol{O})$ or with $0.3 \mu \mathrm{mol} / \mathrm{l}(\square)$ or $1 \mu \mathrm{mol} / 1$ calphostin $\mathrm{C}(\bigcirc)\left(\mathrm{Calph}_{0.3 \text { or } 1}\right)$ and with $16.7 \mathrm{mmol} / \mathrm{l}$ glucose $\left(\mathrm{Gl}_{16.7}\right), 0.16 \mu \mathrm{mol} / \mathrm{l}$ TPA $\left(\mathrm{TPA}_{0.16}\right)$ and $10 \mu \mathrm{mol} / \mathrm{l}$ forskolin $\left(\right.$ Forsk $\left._{10}\right)$ as indicated. Results are means \pm SEM $(n=3-6)$

tively. At $60 \mathrm{mmol} / 1 \mathrm{~K}^{+}$, palmitate augmented insulin secretion at $3.3,10$ and $16.7 \mathrm{mmol} / \mathrm{l}$ glucose, however, was impaired (Fig. 2B).

Effects of palmitate on $\mathrm{K}^{+}{ }_{\text {ATP }}$ channel-independent, $\mathrm{Ca}^{2+}$-independent insulin secretion. Pre-incubation for $60 \mathrm{~min}$ with palmitate failed to increase TPA-induced insulin secretion in the presence (Fig. 3A) or absence (Fig. 3B) of forskolin $(10 \mu \mathrm{mol} / \mathrm{l})$ both with added extracellular $\mathrm{Ca}^{2+}$, or in the presence of the $\mathrm{L}$ type $\mathrm{Ca}^{2+}$ channel inhibitor verapamil $(100 \mu \mathrm{mol} / \mathrm{l})$ (Fig. 3C).

In the absence of concomitant $\mathrm{Ca}^{2+}$ influx, glucose also did not appear to increase TPA-induced insulin secretion (Fig.3D). In the presence of verapamil $(100 \mu \mathrm{mol} / \mathrm{l})$, insulin secretion at $16.7 \mathrm{mmol} / \mathrm{l}$ glucose was not higher than the basal secretion ( $p>0.05$ vs $3.3 \mathrm{mmol} / 1$ glucose) and increased only slightly when TPA was added ( $p<0.05$ vs $3.3 \mathrm{mmol} / 1$ glucose).

Effects of calphostin C on glucose-, TPA- and forskolin-induced insulin secretion. Calphostin $\mathrm{C}$, a specific inhibitor of protein kinase $\mathrm{C}$, failed to inhibit glucose 


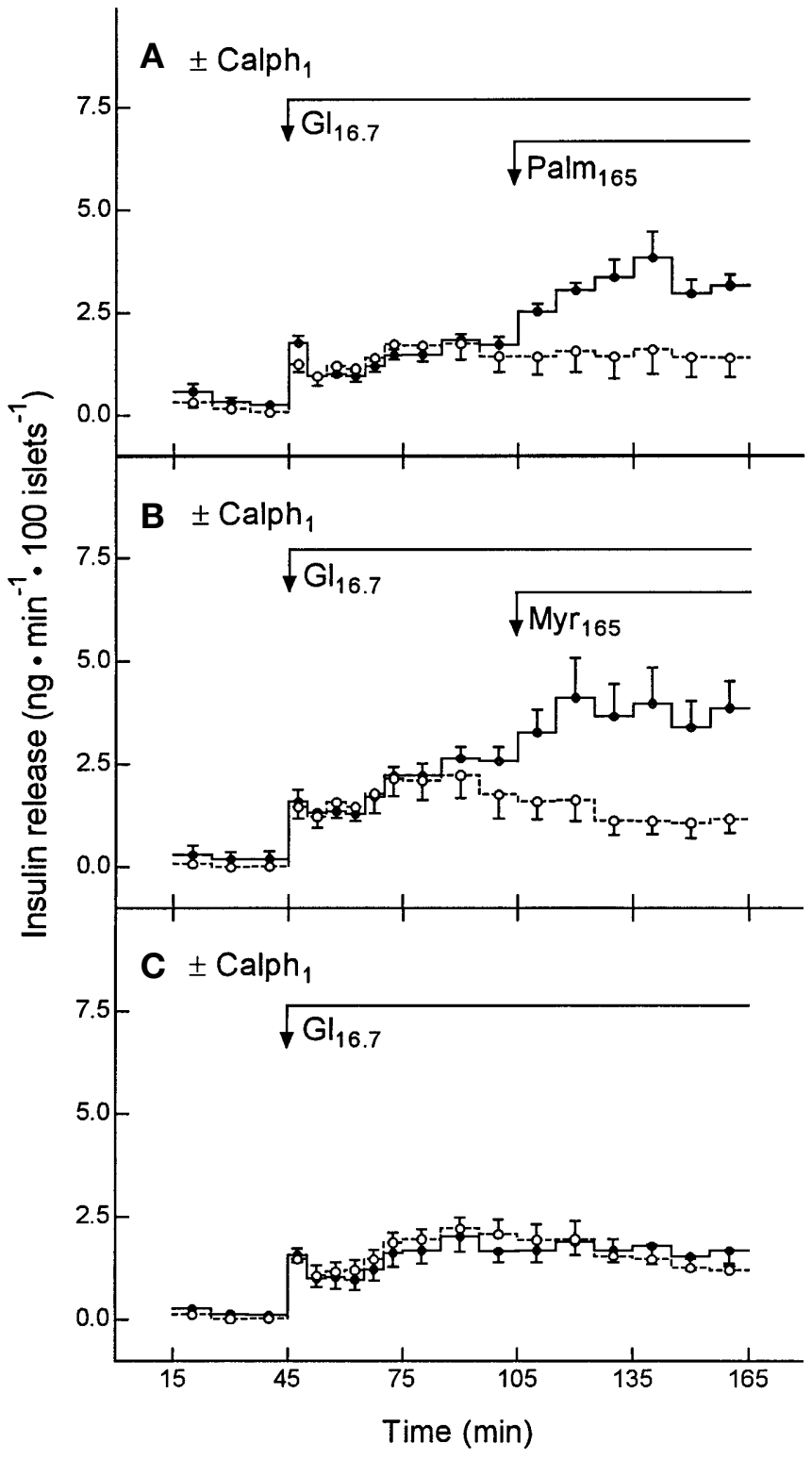

Fig. 5. Effects of calphostin $\mathrm{C}$ on palmitate- and myristate-induced insulin secretion. Islets were perifused without $(\bigcirc)$ or with $1 \mu \mathrm{mol} / \mathrm{l}$ calphostin $\mathrm{C}(\bigcirc)\left(\mathrm{Calph}_{1}\right)$ and with $16.7 \mathrm{mmol} / \mathrm{l}$ glucose $\left(\mathrm{Gl}_{16.7}\right), 165 \mu \mathrm{mol} / \mathrm{l}$ palmitate $\left(\mathrm{Palm}_{165}\right)$ and $165 \mu \mathrm{mol} / \mathrm{l}$ myristate $\left(\mathrm{Myr}_{165}\right)$ as indicated Results are means $\pm \mathrm{SEM}$ $(n=3-8)$

(16.7 mmol/1)-induced insulin secretion but caused a dose-dependent inhibition of TPA $(0.16 \mu \mathrm{mol} / 1)$ induced secretion with complete suppression at $1 \mu \mathrm{mol} / 1$ of calphostin C (Fig. 4A). The specificity of this action was confirmed by the observation that forskolin $(10 \mu \mathrm{mol} / \mathrm{l})$-induced insulin secretion did not appear to be affected by the presence of calphostin C $(1 \mu \mathrm{mol} / \mathrm{l})($ Fig. 4B) .

Effects of calphostin C on palmitate- and myristate-induced insulin secretion. Supporting a role for protein kinase $\mathrm{C}$ in the palmitate stimulation of insulin secre-

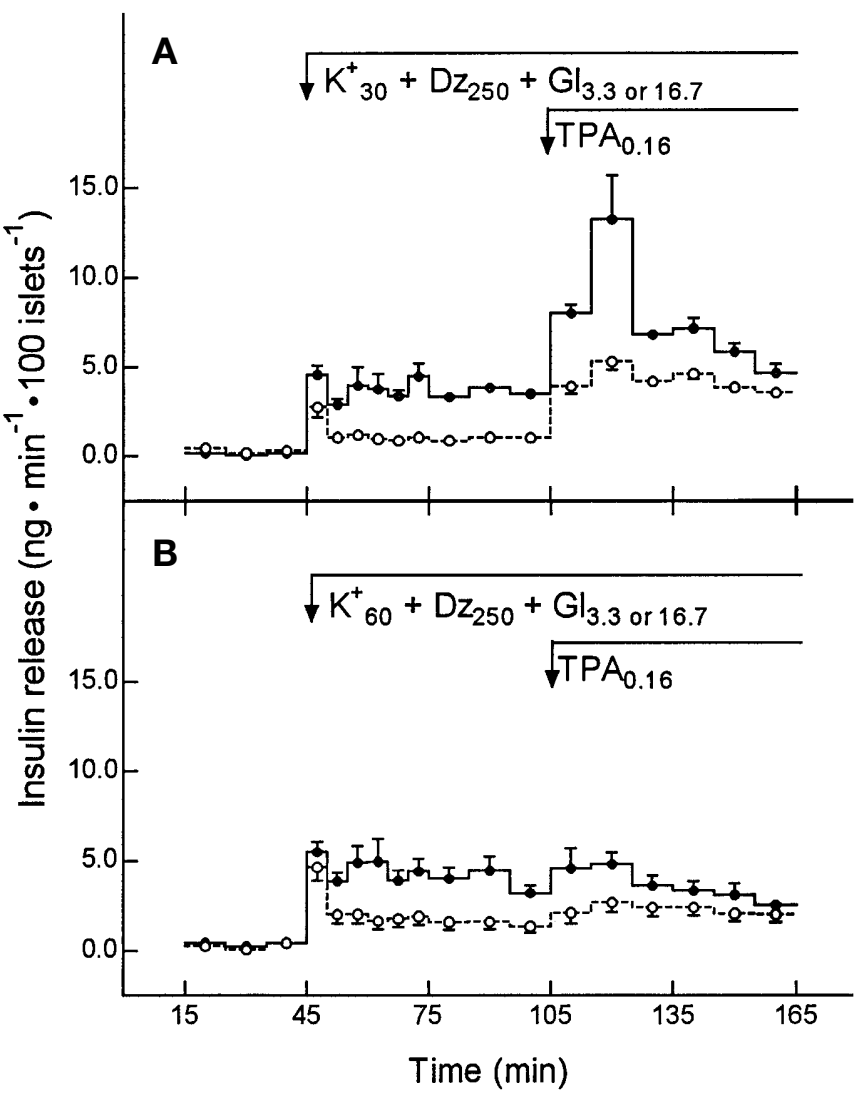

Fig. 6A, B. Effects of TPA on $\mathrm{K}^{+}{ }_{\text {ATP }}$ channel-independent, $\mathrm{Ca}^{2+}$-dependent insulin secretion. Islets were perifused at (A) $30 \mathrm{mmol} / \mathrm{l} \mathrm{K}^{+}+250 \mu \mathrm{mol} / \mathrm{l}$ diazoxide $\left(\mathrm{K}^{+}{ }_{30}+\mathrm{Dz}_{250}\right)$ or $(\mathbf{B})$ $60 \mathrm{mmol} / \mathrm{l} \mathrm{K} \mathrm{K}^{+}+250 \mu \mathrm{mol} / \mathrm{l}$ diazoxide $\left(\mathrm{K}^{+}{ }_{60}+\mathrm{Dz}_{250}\right)$ with 3.3 $(\bigcirc)$, or $16.7 \mathrm{mmol} / \mathrm{l}$ glucose $(\bigcirc)\left(\mathrm{Gl}_{3.3}\right.$ or 16.7$)$ and $0.16 \mu \mathrm{mol} / \mathrm{l}$ TPA $\left(\mathrm{TPA}_{0.16}\right)$ as indicated. Results are means \pm SEM $(n=3-4)$

tion, calphostin $\mathrm{C}(1 \mu \mathrm{mol} / \mathrm{l})$ entirely suppressed the effects of palmitate stimulation on glucose (16.7 mmol/1)-induced insulin secretion (Fig. 5A). Similar results were obtained when palmitate was replaced by myristate $(165 \mu \mathrm{mol} / \mathrm{l}$ total, $2.4 \mu \mathrm{mol} / \mathrm{l}$ free) (Fig. 5B). This effect was not accompanied by an inhibition of glucose-induced insulin secretion at late time points (Fig. 5C).

Effects of TPA on $\mathrm{K}^{+}{ }_{\text {ATP }}$ channel-independent, $\mathrm{Ca}^{2+}$ dependent insulin secretion. For a comparison with palmitate, we investigated the effect of depolarising $\mathrm{K}^{+}$concentrations on TPA stimulation of insulin secretion (Fig. 6). These experiments were performed at 30 and $60 \mathrm{mmol} / 1 \mathrm{~K}^{+}$with $250 \mu \mathrm{mol} / \mathrm{l}$ diazoxide, where glucose $(16.7 \mathrm{mmol} / \mathrm{l})$ increases insulin secretion.

At $30 \mathrm{mmol} / 1 \mathrm{~K}^{+}$, TPA $(0.16 \mu \mathrm{mol} / \mathrm{l})$ increased insulin secretion at both 3.3 and $16.7 \mathrm{mmol} / \mathrm{l}$ glucose (Fig. 6A). Thus TPA stimulated insulin secretion $265 \%$ at $3.3 \mathrm{mmol} / \mathrm{l}$ glucose $(p<0.01)$ and $106 \%$ at $16.7 \mathrm{mmol} / \mathrm{l}$ glucose $(p<0.001)$. At $60 \mathrm{mmol} / \mathrm{l} \mathrm{K}^{+}$, however, no stimulation by TPA at either 3.3 or $16.7 \mathrm{mmol} / \mathrm{l}$ glucose occurred (Fig. 6B). 


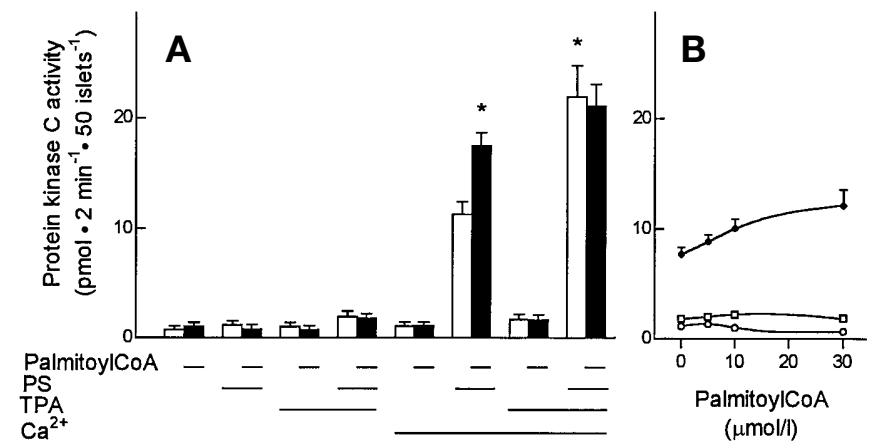

Fig. 7 A, B. Effects of palmitoylCoA on protein kinase $\mathrm{C}$ activity. A Soluble islet protein kinase $\mathrm{C}$ activity in the absence and presence of $30 \mu \mathrm{mol} / \mathrm{l}$ palmitoylCoA was determined in the presence of PS $(50 \mu \mathrm{g} / \mathrm{ml})$, TPA $(32 \mathrm{nmol} / \mathrm{l})$ and $/ \mathrm{or} \mathrm{Ca}^{2+}$ $(100 \mu \mathrm{mol} / \mathrm{l})$ as indicated. Results are means \pm SEM $(n=5)$. $* p<0.001$. B Dose-action relation for palmitoylCoA in the presence of PS $(50 \mu \mathrm{g} / \mathrm{ml})(\bigcirc)$, TPA $(32 \mathrm{nmol} / \mathrm{l})+$ PS $(50 \mu \mathrm{g} /$ $\mathrm{ml})(\square)$ and $\mathrm{Ca}^{2+}(100 \mu \mathrm{mol} / \mathrm{l})+\mathrm{PS}(50 \mu \mathrm{g} / \mathrm{ml})(\mathbf{O})$, respectively. Results are means $\pm \operatorname{SEM}(n=4)$

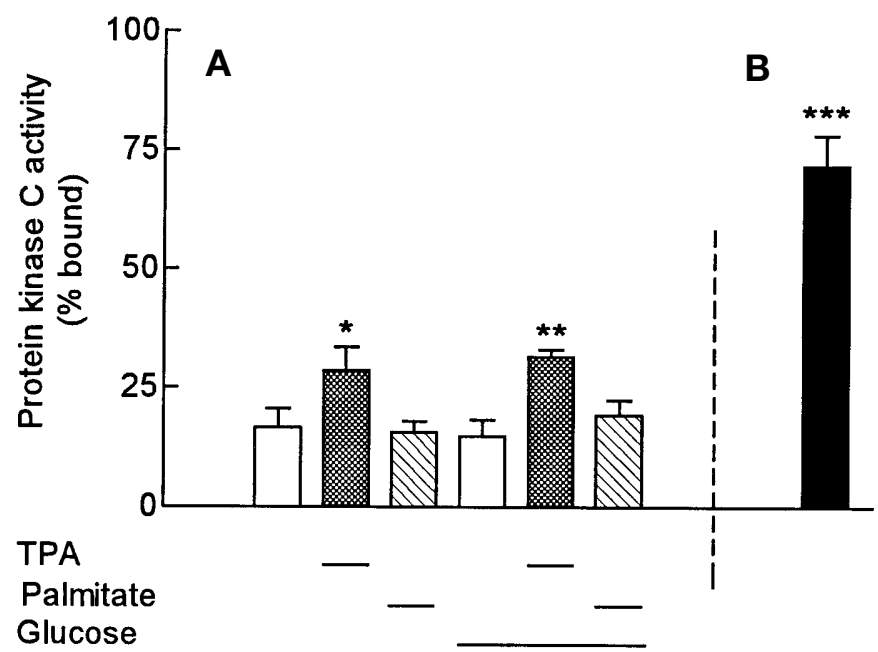

Fig. 8 A, B. Effects of palmitate and TPA on protein kinase C translocation. Islets were incubated for $15 \mathrm{~min}$ in the absence or presence of $0.16 \mu \mathrm{mol} / 1 \mathrm{TPA}, 165 \mu \mathrm{mol} / 1$ palmitate and/or $16.7 \mathrm{mmol} / \mathrm{l}$ glucose as indicated. Soluble and membrane fractions were isolated in the absence $(\mathbf{A})$ or presence $(\mathbf{B})$ of $\mathrm{Ca}^{2+}$ $(100 \mu \mathrm{mol} / \mathrm{l})$. Protein kinase $\mathrm{C}$ activity was then determined in the presence of $\mathrm{Ca}^{2+}(100 \mu \mathrm{mol} / \mathrm{l})+\mathrm{TPA}(32 \mathrm{nmol} / \mathrm{l})+\mathrm{PS}$ $(50 \mu \mathrm{g} / \mathrm{ml})$ as described in Methods. Results are means \pm SEM $(n=4)$ and show the percentage of the total activity localized to the membrane fraction. $* p<0.05 ; * * p<0.01 ; * * * p<0.001$

Effects of palmitoylCoA on protein kinase $C$ activity. PalmitoylCoA $30 \mu \mathrm{mol} / \mathrm{l}$, apparently the maximum stimulatory concentration (Fig. 7B), significantly stimulated $\left(\mathrm{Ca}^{2+}+\mathrm{PS}\right)$-dependent protein kinase $\mathrm{C}$ activity (Fig. 7). This activation does not represent a PS-like effect on protein kinase $\mathrm{C}$ activity because palmitoylCoA failed to support $\mathrm{Ca}^{2+}$-stimulated activity in the absence of PS. PalmitoylCoA could, however, compensate for diacylglycerol activation, because palmitoylCoA failed to support $\left(\mathrm{Ca}^{2+}+\mathrm{PS}\right)$ - stimulated activity in the presence of diacylglycerol analogue TPA, which in the presence of $\mathrm{Ca}^{2+}$ and PS, stimulated protein kinase $\mathrm{C}$ activity (Fig. 7).

Although these results suggest that palmitoylCoA activates $\mathrm{Ca}^{2+}$-dependent, conventional protein kinase $\mathrm{C}$ isoforms, palmitoylCoA failed to affect activity ascribed to novel and atypical protein kinase $\mathrm{C}$ isoforms as shown by the presence of TPA + PS, which could represent $\mathrm{Ca}^{2+}$-independent, but diacylglycerol-dependent, novel protein kinase $\mathrm{C}$ isoforms. Furthermore, palmitoylCoA failed to stimulate activity in the presence of PS alone, which could hint at $\mathrm{Ca}^{2+}$ - and diacylglycerol-independent, but PS-dependent, atypical protein kinase C isoforms (Fig. 7).

Effects of palmitate and TPA on protein kinase $C$ translocation. In other experiments, we investigated the ability of palmitate to stimulate chelator-stable, irreversible translocation of protein kinase $\mathrm{C}$ in mouse islets (Fig. 8). In contrast to TPA, which doubled the membrane-associated activity observed in the presence of $\mathrm{Ca}^{2+}$, TPA and PS, palmitate $(165 \mu \mathrm{mol} / \mathrm{l}$ total, $1.2 \mu \mathrm{mol} / \mathrm{l}$ free) failed to cause chelator-stable translocation of protein kinase $\mathrm{C}$ after $15 \mathrm{~min}$ of incubation in the presence of 3.3 or $16.7 \mathrm{mmol} / \mathrm{l}$ glucose (Fig. 8A). These data, which were obtained after the isolation of protein kinase $\mathrm{C}$ in the presence of EGTA, might only represent a minor fraction of membrane-associated protein kinase $\mathrm{C}$ activity. Thus extraction in the presence of $\mathrm{Ca}^{2+}$, which could cause reversible translocation of protein kinase $\mathrm{C}$, increased membrane-associated activity fourfold (Fig. 8B).

These results mainly reflect the activity of conventional $\mathrm{Ca}^{2+}$-dependent protein kinase $\mathrm{C}$ isoforms (Fig.7). Separate experiments to determine palmitate-induced translocation of atypical protein kinase $\mathrm{C}$ isoforms, which seem to represent a minor activity in mouse islets (Fig.7) were, however, negative (results not shown).

\section{Discussion}

A previous study on mouse islets suggested that palmitate stimulation of $\mathrm{K}^{+}$-induced insulin secretion was dependent on glucose, which facilitated palmitate stimulation of insulin secretion by a mechanism that is still not known [9]. A direct stimulation of $\mathrm{K}^{+}$induced secretion at a non-stimulatory glucose concentration was, however, also observed in a recent study in rat islets, where it was facilitated by pre-incubation in $\mathrm{Ca}^{2+}$-deprived medium [11]. The mechanism for this could not be explained by an increased uptake of fatty acids in $\mathrm{Ca}^{2+}$-deprived medium [11]. Our experiments suggest this facilitation could be explained by a reduction of intracellular $\mathrm{Ca}^{2+}$ because palmitate stimulation, was inhibited at maximum stimulating concentrations of $\mathrm{Ca}^{2+}$, which appear to 
substitute for the stimulating effect of the fatty acid. Thus fatty acids could increase the secretory response to both glucose and non-glucose stimuli [13].

In accordance with other data on mouse islets [9], however, palmitate facilitated glucose stimulation of $\mathrm{K}^{+}{ }_{\text {ATP }}$ channel-independent, $\mathrm{Ca}^{2+}$-dependent insulin secretion at a low depolarising concentration of $\mathrm{K}^{+}$. A similar facilitation of glucose stimulation was also observed on raising the intracellular $\mathrm{Ca}^{2+}$ concentration by maximum depolarising concentrations of $\mathrm{K}^{+}$. This facilitation of glucose stimulation by fatty acids could be explained by an increase in $\mathrm{Ca}^{2+}$-mediated insulin secretion, which appears to be a requirement for glucose stimulation of $\mathrm{K}^{+}{ }_{\text {ATP }}$ channel-independent insulin secretion.

Glucose stimulation of $\mathrm{K}^{+}{ }_{\text {ATP }}$ channel-independent insulin secretion has been found to include both $\mathrm{Ca}^{2+}$-dependent and $\mathrm{Ca}^{2+}$-independent steps [1-4]. Thus glucose could also stimulate $\mathrm{K}^{+}{ }_{\text {ATP }}$ channel-independent, $\mathrm{Ca}^{2+}$-independent insulin secretion in rat islets $[1,4]$. The physiological importance of this pathway has been disputed but similar experiments with mouse islets have confirmed that the capacity of glucose to stimulate under conditions with mild $\mathrm{Ca}^{2+}$ deprivation is considerably less [29], as is also suggested by the present study. In contrast to rat islets, where palmitate has been described to mimic glucose stimulation [12], we failed to demonstrate palmitate stimulation of $\mathrm{K}^{+}{ }_{\text {ATP }}$ channel-independent, $\mathrm{Ca}^{2+}$-independent insulin secretion in mouse islets with mild $\mathrm{Ca}^{2+}$ deprivation. The reason for this discrepancy is not known.

Our experiments suggest that palmitate, unlike glucose, stimulates insulin secretion by activating protein kinase $\mathrm{C}$. Thus palmitate and myristate stimulation of insulin secretion were inhibited by the specific protein kinase $\mathrm{C}$ inhibitor calphostin $\mathrm{C}$ [30], which specifically inhibited protein kinase C-mediated insulin secretion and failed to inhibit glucose-induced or protein kinase A-mediated insulin release. Furthermore, the protein kinase $\mathrm{C}$ activator TPA, which is known to sensitize the exocytotic machinery to $\mathrm{Ca}^{2+}$ [31], shared the ability of palmitate to also stimulate at moderate but not maximum depolarising concentrations of $\mathrm{K}^{+}$.

Fatty acids could therefore not be the missing link in glucose increase of $\mathrm{K}^{+}{ }_{\text {ATP }}$ channel-independent insulin secretion, leaving this action by glucose still to be explained. Extensive studies, however, point to a possible role for ATP [10], while another study has identified glutamate as a possible signalling molecule in glucose amplification of $\mathrm{K}^{+}{ }_{\text {ATP }}$ channel-independent insulin release [32].

According to our present experiments, palmitoyl$\mathrm{CoA}$ could activate conventional $\mathrm{Ca}^{2+}$-dependent protein kinase $\mathrm{C}$ isoforms, like the universally expressed protein kinase $\mathrm{C} \alpha$ [33], which appears to be the predominant isoform in mouse islet beta cells
$[34,35]$. Palmitate stimulation of insulin secretion, which appears to be dependent on $\mathrm{Ca}^{2+}$ influx, could therefore be explained by an activation of $\mathrm{Ca}^{2+}$-dependent protein kinase $\mathrm{C}$ activity after $\mathrm{Ca}^{2+}$-induced association of protein kinase $\mathrm{C}$ with membranes.

In accordance with one [36] although not another study [37], palmitoylCoA appeared to compensate for TPA in the activation of $\mathrm{Ca}^{2+}$-dependent protein kinase $\mathrm{C}$ activity. Unlike TPA, however, palmitate failed to induce irreversible, chelator-stable translocation of $\mathrm{Ca}^{2+}$-dependent protein kinase $\mathrm{C}$ activity. Translocation of protein kinase $\mathrm{C}$ is normally associated with the formation of bioactive diacylglycerol molecules, which could be formed in pancreatic islets in response, for example, to carbacholin activation of phospholipase $\mathrm{C}$ [38]. The combined addition of palmitate and glucose could stimulate diacylglycerol accumulation. Saturated diacylglycerols, such as dipalmitate, however, do not activate protein kinase C [39].

A recent study suggested palmitate stimulation of insulin secretion in MIN 6 cells could be explained by the activation of the atypical, $\mathrm{Ca}^{2+}$ - and diacylglycerol-independent, but PS-dependent $\xi$ isoform of protein kinase $\mathrm{C}$ a [21]. A role for $\mathrm{Ca}^{2+}$-dependent protein kinase $\mathrm{C}$ isoforms was excluded because of their susceptibility to down regulation by TPA without apparent diminution of fatty acid-induced insulin secretion [21]. In the present study, we were reluctant to carry out down regulation experiments based on protein kinase $\mathrm{C}$ activators like TPA because this procedure could lead to aberrant effects and persistent phosphorylation of endogenous proteins [40]. We, therefore, cannot exclude the possibility that palmitoylCoA stimulates insulin secretion through the activation of an atypical protein kinase $\mathrm{C}$ isoform, although we failed to detect palmitoylCoA activation of PS-dependent, $\mathrm{Ca}^{2+}$ - and diacylglycerol-independent protein kinase $\mathrm{C}$ activity.

According to another study [21], fatty acid stimulation of insulin secretion by the activation of protein kinase $\mathrm{C} \zeta$ supports the long-chain acylCoA hypothesis because not only palmitate but also glucose could activate this isoform. This isozyme is, however, sensitive to calphostin $C$ [22] which did not inhibit glucose-induced insulin secretion in our experiments. It is possible that protein kinase $\mathrm{C} \zeta$ participates in glucose stimulation of insulin biosynthesis in rat islets [24] unlike fatty acids [41].

Endogenous long-chain acylCoAs did not activate protein kinase $\mathrm{C}$ in our experiments. Previous studies have, however, identified different long-chain acylCoA species in islet cells [6-8] and it is possible that long-chain acylCoA concentrations could fluctuate in different islet preparations depending on islet culture conditions, the nutritional status, strain and animal species. Such fluctuations could explain the inconsistent outcomes of previous studies, which have been both positive and negative as regards the in- 
volvement of protein kinase $\mathrm{C}$ in glucose-induced insulin secretion [25, 40, 42]. Indeed, freshly isolated pancreatic islets are known to lose sensitivity to glucose during islet culture, a feature that has been associated with a reduction of protein kinase $\mathrm{C}$ activation [40]. Furthermore, in vivo studies have shown, that nicotinic acid, an inhibitor of lipolysis, could deprive fasted animals of serum fatty acids and inhibit insulin secretion to both glucose and non-glucose stimuli, in such a way that is compensated by application of lard oil $[13,14]$.

In conclusion, our results suggest that glucose stimulation of $\mathrm{K}^{+}{ }_{\text {ATP }}$ channel-independent insulin secretion could occur independently of saturated fatty acids like palmitate acid and myristate, which appear to increase glucose-induced insulin secretion by activating protein kinase $\mathrm{C}$.

Acknowledgements. This work was supported by the Danish Diabetes Association and Novo's Foundation. The skilful technical assistance of L. Høyer is highly appreciated.

\section{References}

1. Komatsu M, Schermerhorn T, Noda M, Straub SG, Aizawa T, Sharp GWG (1997) Augmentation of insulin release by glucose in the absence of extracellular $\mathrm{Ca}^{2+}$. Diabetes 46 : 1928-1938

2. Gembal M, Gilon P, Henquin JC (1992) Evidence that glucose can control insulin release independently from its action on ATP-sensitive $\mathrm{K}^{+}$channels in mouse B cells. J Clin Invest 89: 1288-1295

3. Sato Y, Aizawa T, Komatsu M, Okada T, Yamada T (1992) Dual functional role of membrane depolarization $/ \mathrm{Ca}^{2+}$ influx in rat pancreatic B-cell. Diabetes 41: 438-443

4. Komatsu M, Schermerhorn T, Aizawa T, Sharp GWG (1995) Glucose stimulation of insulin release in the absence of extracellular $\mathrm{Ca}^{2+}$ and in the absence of any increase in intracellular $\mathrm{Ca}^{2+}$ in rat pancreatic islets. Proc Natl Acad Sci USA 92: 10728-10732

5. Corkey BE, Glennon MC, Chen KS, Deeney JT, Matschinsky FM, Prentki M (1989) A role for malonyl CoA in glucose-stimulated insulin secretion from clonal pancreatic $\beta$ cells. J Biol Chem 264: 21608-21612

6. Prentki M, Vischer S, Glennon MC, Regazzi R, Deeney JT, Corkey BE (1992) Malonyl-CoA and long chain acyl-CoA esters as metabolic coupling factors in nutrient-induced insulin secretion. J Biol Chem 267: 5802-5810

7. Prentki M, Tornheim K, Corkey BE (1997) Signal transduction mechanisms in nutrient-induced insulin secretion. Diabetologia 40: S32-S41

8. Antinozzi PA, Segall L, Prentki M, McGarry JD, Newgard CB (1998) Molecular or pharmacologic pertubation of the link between glucose and lipid metabolism is without effect on glucose-stimulated insulin secretion. J Biol Chem 273: 16146-16154

9. Warnotte C, Gilon P, Nenquin M, Henquin JC (1994) Mechanisms of the stimulation of insulin release by saturated fatty acids. Diabetes 43: 703-711

10. Sato Y, Henquin JC (1998) The $\mathrm{K}^{+}$-ATP channel-independent pathway of regulation of insulin secretion by glucose. Diabetes 47: 1713-1721
11. Komatsu M, Yajima H, Yamada S et al. (1999) Augmentation of $\mathrm{Ca}^{2+}$-stimulated insulin release by glucose and long-chain fatty acids in rat pancreatic islets. Diabetes 48 : 1543-1549

12. Komatsu M, Sharp GWG (1998) Palmitate and myristate selectively mimic the effect of glucose in augmenting insulin release in the absence of extracellular $\mathrm{Ca}^{2+}$. Diabetes 47: $352-357$

13. Dobbins RL, Chester MW, Stevenson BE, Daniels MB, Stein DT, McGarry JD (1998) A fatty acid-dependent step is critically important for both glucose- and non-glucose-stimulated insulin secretion. J Clin Invest 101: 2370-2376

14. McGarry JD, Dobbins RL (1999) Fatty acids, lipotoxicity and insulin secretion. Diabetologia 42: 128-138

15. Conget I, Rasschaert J, Sener A et al. (1994) Secretory, biosynthetic, respiratory, cationic and metabolic responses of pancreatic islets to palmitate and oleate. Biochem Medi Metab Biol 51: 175-184

16. Bränström R, Leibiger IB, Leibiger B, Corkey B, Berggren PO, Larsson O (1998) Long chain coenzyme A esters activate the pore-forming subunit (Kir6.2) of the ATP-regulated potassium channel. J Biol Chem 273: 31395-31400

17. Alcázar O, Qiu-yue Z, Giné E, Tamarit-Rodriguez J (1997) Stimulation of islet protein kinase $\mathrm{C}$ translocation requires metabolism of the fatty acid. Diabetes 46: 1153-1158

18. Littman ED, Pitchumoni S, Garfinkel MR, Opara E (2000) Role of protein kinase $\mathrm{C}$ isoenzymes in fatty acid stimulation of insulin secretion. Pancreas 20: 256-263

19. Deeney JT, Gromada J, Høy M, Olsen HL, Rhodes CJ, Prentki M, Berggren PO, Corkey BE (2000) Acute stimulation with long chain acyl-CoA enhances exocytosis in insulin-secreting cells (HIT T-15 and NMRI $\beta$-cells). J Biol Chem 275: 9363-9368

20. Tian YM, Urquidi V, Ashcroft SJ (1996) Protein kinase C in $\beta$-cells: expression of multiple isoforms and involvement in cholinergic stimulation of insulin secretion. Mol Cell Endocrinol 119: 185-193

21. Yaney GC, Korchak HM, Corkey BE (2000) Long-chain acyl CoA regulation of protein kinase $\mathrm{C}$ and fatty acid potentiation of glucose-stimulated insulin secretion in clonal $\beta$-cells. Endocrinology 141: 1989-1998

22. Larivée P, Levine SJ, Martinez A, Wu T, Logun C, Shelhamer JH (1994) Platelet-activating factor induces airway mucin release via activation of protein kinase $\mathrm{C}$ : evidence for translocation of protein kinase $\mathrm{C}$ to membranes. Am J Respir Cell Mol Biol 11: 199-205

23. Seynaeve CM, Kazanietz MG, Blumberg PM, Sausville EA, Worland PJ (1994) Differential inhibition of protein kinase C isozymes by UNC-01, a staurosporine analogue. Mol Pharmacol 45: 1207-1214

24. Furukawa N, Shirotani T, Araki E et al. (1999) Possible involvement of atypical protein kinase C (PKC) in glucosesensitive expression of human insulin gene: DNA-binding activity and transcriptional activity of pancreatic and duodenal homeobox gene-1 (PDX-1) are enhanced via calphostin C-sensitive but phorbol 12-myristate 13-acetate (PMA) and Gö 6976-insenstive pathway. Endocrine J 46: 43-58

25. Thams P, Capito K, Hedeskov CJ, Kofod H (1990) Phorbol-ester-induced down-regulation of protein kinase $\mathrm{C}$ in mouse pancreatic islets. Biochem J 265: 777-787

26. Thams P, Hedeskov CJ, Capito K (1993) Exogenous arachidonic acid inactivates protein kinase $\mathrm{C}$ in mouse pancreatic islets. Acta Physiol Scand 149: 227-235

27. Spector AA (1975) Fatty acid binding to plasma albumin. J Lipid Res. 16: 165-179 
28. Ashbrook JD, Spector AA, Santon EC, Fletcher JE (1975) Long chain fatty acid binding to human plasma albumin. J Biol Chem 250: 2333-2338

29. Sato Y, Nenquin M, Henquin JC (1998) Relative contribution of $\mathrm{Ca}^{2+}$-dependent and $\mathrm{Ca}^{2+}$-independent mechanisms to the regulation of insulin secretion by glucose. FEBS Letters 421: 115-119

30. Rotenberg SA, Huang MH, Zhu J, Su L, Riedel H (1995) Depletion analysis of protein kinase $\mathrm{C}$ inactivation by calphostin C. Mol Carcinog 12: 42-49

31. Hughes SJ, Christie MR, Ashcroft SJH (1987) Potentiators of insulin secretion modulate $\mathrm{Ca}^{2+}$ sensitivity in rat pancreatic islets. Mol Cell Endocrinol 50: 231-236

32. Maechler P, Wollheim CB (1999) Mitochondrial glutamate acts as a messenger in glucose-induced insulin exocytosis. Nature 402: 685-689

33. Nakamura SI, Nishizuka Y (1994) Lipid mediators and protein kinase $\mathrm{C}$ activation for the intracellular signaling network. J Biochem 115: 1029-1034

34. Zawalich WS, Bonnet-Eymard M, Zawalich KC (2000) Insulin secretion, inositol phosphate levels and phospholipase $\mathrm{C}$ isozymes in rodent pancreatic islets. Metabolism 49: $1156-1163$

35. Arkhammar P, Juntti-Berggren L, Larsson O et al. (1994) Protein kinase $\mathrm{C}$ modulates the insulin secretory process by maintaining a proper function of the $\beta$-cell voltage activated $\mathrm{Ca}^{2+}$-channels. J Biol Chem 269: 2743-2749
36. Shinomura T, Asaoka Y, Oka M, Yoshida K, Nishizuka Y (1991) Synergistic action of diacylglycerol and unsaturated fatty acid for protein kinase $\mathrm{C}$ activation: Its possible implications. Proc Natl Acad Sci USA 88: 5149-5153

37. Nesher M, Boneh A (1994) Effect of fatty acids and their acyl-CoA esters on protein kinase $\mathrm{C}$ activity in fibroblasts: possible implications in fatty acid oxidation defects. Biochim Biophys Acta 1221: 66-72

38. Persaud SJ, Jones PM, Sugden D, Howell SL (1989) The role of protein kinase $\mathrm{C}$ in cholinergic stimulation of insulin secretion from rat islets. Biochem J 264: 753-758

39. Goldberg EM, Zidovetzki R (1997) Effects of dipalmitoylglycerol and fatty acids on membrane structure and protein kinase C activity. Biophys J 73: 2603-2614

40. Zawalich WS, Bonnet-Eymard M, Zawalich KC, Yaney GC (1998) Chronic exposure to TPA depletes PKC $\alpha$ and augments Ca-dependent insulin secretion from cultured rat islets. Am J Physiol 274: C1388-C1396

41. Skelly RH, Bollheimer LC, Wicksteed BL, Corkey BE, Rhodes CJ (1998) A distinct difference in the metabolic stimulus-response coupling pathways for regulating proinsulin biosynthesis and insulin secretion that lies at the level of a requirement for fatty acyl moieties. Biochem J 331: 553-561

42. Hii CST, Jones PM, Persaud SJ, Howell SL (1987) A re-assessment of the role of protein kinase $\mathrm{C}$ in glucose-stimulated insulin secretion. Biochem J 246: 489-494 